POLITEKNIK NEGERI NUSA UTARA

\title{
ANALISIS INDEKS GLIKEMIK DAN KANDUNGAN GIZI SAGU PORNO
}

\section{ANALYSIS OF THE GLYCEMIC INDEX AND THE NUTRITIONAL CONTENT OF SAGU PORNO}

\author{
Dhito Dwi Pramardika, Ferdinand Gansalangi \\ Program Studi Keperawatan, Politeknik Negeri Nusa Utara \\ Email: dhitodwi@gmail.com
}

\begin{abstract}
Abstrak: Di Kabupaten Sangihe terdapat satu pangan lokal yang terkenal yaitu bernama "Sagu Porno". Panganan khas asli dari suku Sangihe yang terbuat dari tanaman sagu yang diolah dengan cara dibakar. Masyarakat sangihe memepercayai bahwa makanan ini bagus jika dikonsumsi penderita diabetes. Namun penelitian ilmiah mengenai pangan tersebut masih sangat minim. Berdasarkan hal tersebut, penelitian ini dilakukan dengan tujuan untuk menganalisis indeks glikemik dan kandungan gizi pada Sagu Porno. Penelitian ini merupakan penelitian eksperimen. Lokasi pengujian kandungan gizi dilaksanakan di Laboratorium Balai Riset dan Standarisasi Industri Kota Manado sedangkan untuk pengukuran indeks glikemik dilakukan di Politeknik Negeri Nusa Utara. Subjek pada penelitian ini sebanyak 14 responden dan objek pada penelitian ini adalah sagu porno. Berdasarkan hasil uji kandungan gizinya, sagu porno memiliki kandungan karbohidrat sebanyak 50,65\%, protein 2,06\%, lemak 11,75\% dan serat kasar 3,12\%. Berdasarkan hasil uji kandungan indeks glikemiknya diketahui bahwa sagu porno adalah $296,53 \%$ yang artinya bahwa sagu porno merupakan panganan dengan indeks glikemik tinggi. Kesimpulannya, tidak disarankan penderita diabetes untuk mengkonsumsi panganan sagu porno.
\end{abstract}

Kata Kunci : Gizi Makro, Indeks Glikemik, Sagu Porno,

\begin{abstract}
Sangihe District, famous food as a local food called "Sagu Porno". Secialty original dish from Sangihe tribe, which it was made from the sago plant with burned processed. The people very much believe that those food was good if consumed by diabetics. However, scientific quantity research on those foods were little. Based on those study the aim of analyzing were the glycemic index and nutritional content of Sagu Porno. Those research was an experimental research. The location for testing the nutritional content was on the laboratory Balai Riset dan Standarisasi Industri of Manado City, while for the measurement of the glycemic index at Politeknik Negeri Nusa Utara. The subjects in those study were 14 respondents and the object in those study was Sagu Porno. Based on the results of the nutritional content test, Sagu Porno has a carbohidrate content of 50.65\%, $2.06 \%$ protein, $11.75 \%$ fat, and $3.12 \%$ crude fiber. Based on the results of the glycemic index content test, it was known that Sagu Porno was 296.53\%, which means that Sagu Porno is a food with a high glycemic index. In conclusion, diabetics are not advised to consume Sagu Porno.
\end{abstract}

Key words: Macro Nutrition, Glycemic Index, Sagu Porno

\section{PENDAHULUAN}

Prevalensi diabetes di Indonesia terus meningkat. Berdasarkan data Riset Kesehatan Dasar (Riskesdas) pada tahun 2007 sebesar 5,7\% kemudian meningkat menjadi sebesar 6,9\% di tahun 2013 dan terjadi lagi peningkatan menjadi 8,5\% di tahun 2018 (Kemenkes, 2018). Berdasarkan data tersebut bahwa selama ini program yang dikembangkan oleh pemerintah berfokus pada penanganan penderita Diabetes Melitus dan belum 
ada program pencegahan jangka panjang dalam menanggulanginya.

Pembatasan asupan gula berlebih merupakan cara yang efektif dalam menurunkan prevalensi penyakit tersebut yaitu dengan mengubah menu pangan yang dikonsumsi sehari oleh masyarakat Indonesia seperti nasi. Nasi merupakan pangan yang termasuk dengan pangan berindeks glikemik tinggi yaitu sebesar 89 (Regina, 2012)

Pemerintah Kabupaten Kepulauan Sangihe yang merupakan salah satu dari kabupaten dari provinsi di Sulawesi Utara yang mayoritas masyarakatnya juga mengkonsumsi nasi sebagai sumber karbohidratnya. Berdasarkan hal tersebut, pemerintah Kabupaten Kepulauan Sangihe mempunyai kebijakan melalui peraturan daerahnya yaitu dua hari tanpa nasi. Dalam upaya mendukung program tersebut, maka pemerintah melakukan upaya promotif dengan mengganti nasi dengan sumber karbohidrat lainnya.

Keanekaragaman suku dan budaya membuat Indonesia kaya akan jenis pangannya. Hal itu juga terdapat pada suku Sanger yang merupakan suku asli dari Kabupaten Kepulauan Sangihe. Suku Sanger mempunyai pangan lokal yang digemari oleh masyarakatnya, pangan lokal tersebut adalah sagu porno.

Sagu porno dapat dijadikan alternatif sebagai pengganti nasi. Warga Sangihe mempercayai bahwa makanan ini bagus jika dikonsumsi pada penderita diabetes melitus. Namun penelitian ilmiah mengenai panganan lokal tersebut masih sangat minim. Berdasarkan hal tersebut, peneliti tertarik untuk menganalisis indeks glikemik dan kandungan gizi dari sagu porno.

\section{METODE PENELITIAN}

Jenis penelitian yang digunakan adalah eksperimen. Jenis desain rancangan pada penelitian ini yaitu menggunakan one-shot case study. One-shot case study dalam penelitian ini yaitu memberikan perlakuan secara sengaja kepada panelis terhadap pangan acuan nasi putih dan pangan uji sagu porno keduanya kemudian mengukur glukosa darah setelah perlakuan tersebut (Sinulingga, 2012). Lokasi pengujian kandungan gizi dilakukan di Laboratorium Balai Riset dan Standarisasi Industri Kota Manado. Sedangkan pemeriksaan indeks glikemik dilakukan di laboratorium keperawatan jurusan kesehatan Politeknik Negeri Nusa Utara.

Pengujian kandungan gizi makro seperti karbohidrat dengan metode SNI 01-2891-1992 butir 9, pengujian protein dengan metode SNI 01-2986-1992 butir 5.5, pengujian lemak dengan SNI 01-2891-1992 butirb8.1 dan serat kasar diuji dengan metode SNI 012891-1992 butir 11. Sedangkan pengujian indeks glikemik dengan pemilihan subjek sebanyak 14 responden yang dilakukan secara selective sampling dengan kriteria laki-laki dan perempuan, berumur 18-35 tahun dan dalam keadaan sehat.. Subjek yang terpilih kemudian diharuskan berpuasa selama 10 jam (kecuali

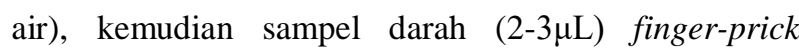
capillary blood diambil menggunakan alat easy touch pada menit ke-0 (saat subjek puasa dan sebelum pemberian pangan uji atau acuan), kemudian subjek mengkonsumsi pangan uji atau acuan kemudian sampel darah subjek akan diambil lagi pada rentang waktu setiap 15 menit dan 30 menit yaitu menit ke-15, 30, 45, 60, 90, 120 setelah subyek diberikan pangan uji atau acuan (Similia, 2012). Dalam satu kali pengukuran indeks glikemik subjek diambil darahnya sebanyak tujuh kali. Penelitian ini telah memperoleh izin dan mendapatkan persetujuan Komisi Etik Penelitian Kesehatan Politeknik Kementerian Kesehatan Manado dengan No. KEPK. 01/08/040/2020.

Sagu porno yang diujikan dibuat dengan komposisi kelapa parut sebanyak 40 gram dan tepung sagu 100 gram yang kemudian dicampur dan dicetak dengan cetakan kemudian dibakar (Hendriadi, 2018). Sedangkan pangan acuan/kontrol pada penelitian ini adalah nasi putih dengan merk dagang beras Merpati. 
Sampel sagu porno dan nasi putih yang diberikan kepada subjek adalah sebanyak 29,4 gram. Pengukuran indeks glikemik yaitu dengan menghitung luas area dibawah kurva menunjukkan respons glukosa darah terhadap pangan (FAO, 1998). Kemudian indeks glikemik dihitung dengan cara luas area dibawah kurva pangan uji dibagi dengan luar area dibawah kurva pangan acuan x 100\% (Monro \& Shaw, 2008). Data diolah menggunakan microsoft excel.

\section{HASIL DAN PEMBAHASAN}

HASIL

Tabel 1. Kandungan gizi sagu porno

\begin{tabular}{lcc}
\hline \multicolumn{1}{c}{$\begin{array}{c}\text { Komposisi zat } \\
\text { gizi }\end{array}$} & Jumlah (\%) & Energi (Kkal) \\
\hline Karbohidrat & 50,65 & 202,6 \\
Protein & 2,06 & 8,24 \\
Lemak & 11,75 & 105,75 \\
Serat Kasar & 3,12 & 6,24 \\
\hline \multicolumn{3}{r}{ Total } \\
\hline
\end{tabular}

Berdasarkan tabel 1 diketahui bahwa pada 100 gram sagu menghasilkan 322,83 kkal energi. Adapun komposisi yang dikandung didalamnya terdiri dari $50,65 \%$ karbohidrat, $2,06 \%$ protein, $11,75 \%$ lemak dan $3,12 \%$ serat kasar.

Tabel 2. karakteristik subyek

\begin{tabular}{cccccc}
\hline Kode & $\begin{array}{c}\text { Jenis } \\
\text { Kelamin } \\
(\mathrm{L} / \mathrm{P})\end{array}$ & $\begin{array}{c}\text { Usia } \\
(\text { thn })\end{array}$ & $\begin{array}{c}\text { Berat } \\
\text { badan } \\
(\mathrm{kg})\end{array}$ & $\begin{array}{c}\text { Tinggi } \\
\text { badan } \\
(\mathrm{m})\end{array}$ & IMT \\
\hline ET & $\mathrm{P}$ & 30 & 60 & 1,59 & 23,73 \\
ME & $\mathrm{P}$ & 19 & 54 & 1,59 & 21,36 \\
JT & $\mathrm{P}$ & 19 & 53 & 163 & 19,95 \\
AV & $\mathrm{P}$ & 19 & 48 & 156 & 19,72 \\
$\mathrm{DO}$ & $\mathrm{P}$ & 21 & 58 & 152 & 25,10 \\
$\mathrm{CK}$ & $\mathrm{P}$ & 19 & 53 & 163 & 19,95 \\
$\mathrm{SS}$ & $\mathrm{P}$ & 20 & 49 & 157 & 19,88 \\
$\mathrm{RM}$ & $\mathrm{P}$ & 19 & 51 & 152 & 22,07 \\
$\mathrm{AK}$ & $\mathrm{P}$ & 19 & 43 & 165 & 15,79 \\
$\mathrm{ES}$ & $\mathrm{P}$ & 19 & 40 & 150 & 17,78 \\
$\mathrm{ES}$ & $\mathrm{P}$ & 19 & 39 & 152 & 16,88 \\
$\mathrm{SK}$ & $\mathrm{P}$ & 31 & 53 & 164 & 19,71 \\
$\mathrm{GO}$ & $\mathrm{P}$ & 18 & 56 & 150 & 24,89 \\
AK & $\mathrm{L}$ & 19 & 45 & 159 & 17,80 \\
\hline
\end{tabular}

Berdasarkan karakteristik subyek diketahui bahwa usia rata-rata subyek adalah 21 tahun. Dari data indeks massa tubuh rata-rata subyek adalah 20,33 dengan perempuan sebanyak 13 subyek dan laki-laki sebanyak 1 subyek.



Gambar 1 Kadar glukosa pangan uji dan kontrol

Berdasarkan kurva diatas, kenaikan kadar glukosa setelah pemberian nasi putih merk Merpati yaitu pada menit ke-15 dan selanjutnya mengalami penurunan hingga menit 120. Berbeda dengan nasi putih sebagai pangan kontrol, pangan uji yaitu sagu porno, kenaikan kadar glukosa darah mengalami puncaknya yaitu pada menit ke-45 dan menurun hingga menit ke120.

Tabel 3 Nilai Indeks glikemik Sagu Porno

\begin{tabular}{ccc}
\hline Makanan uji & $\begin{array}{c}\text { Indeks Glikemik } \\
(\%)\end{array}$ & Kategori \\
\hline Sagu Porno & 296,53 & Tinggi \\
\hline
\end{tabular}

Berdasarkan tabel 3 diketahui bahwa nilai indeks glikemik dari sagu porno dibandingkan dengan pangan kontrol (nasi putih Merpati) adalah sebesar 296,53\% dan termasuk dalam panganan yang memiliki indeks glikemik $>70 \%$ yaitu kategori tinggi.

\section{PEMBAHASAN}

Berdasarkan hasil uji laboratorium dapat diketahui bahwa terdapat perbedaan nilai kandungan gizi dari sagu porno. Hasil uji laboratorium memiliki nilai gizi lebih banyak dibandingkan dengan yang 
terdapat pada tabel komposisi pangan Indonesia. Pada tabel komposisi pangan Indonesia, nilai energi yang dihasilkan dari sagu porno adalah 291 kalori, karbohirat $63,4 \mathrm{~g}$, protein $0,5 \mathrm{~g}$, serat $0 \mathrm{~g}$, dan lemak $4 \mathrm{~g}$ (Kemenkes, 2017)

Perbedaan tersebut dapat terjadi karena komposisi pada bahan yang digunakan. Pada sagu porno yang diuji menggunakan kelapa parut sebanyak $40 \mathrm{~g}$ dan tepung sagu $100 \mathrm{~g}$. Hal itu sesuai dengan pendapat yang mengatakan hasil olahan pangan sangat bervariatif pada zat gizi produk, dikarenakan jenis proses pengolahan, lama proses pengolahan, jenis bahan baku, dan lain-lain (Nurdyansyah dkk., 2019).

Secara komposisi zat gizi sagu porno merupakan pangan yang termasuk dalam karbohidrat kompleks yang dapat dijadikan pangan alternatif selain nasi. Karbohidrat selain memiliki peranan dalam menghasilkan energi, akan tetapi mempunyai peran yang lain bagi tubuh. Karbohidrat memiliki fungsi lain seperti memberikan rasa manis pada makanan, membantu menghemat protein, membantu dalam mengatur metabolisme terhadap lemak, kemudian juga membantu dalam mengeluarkan feses (Siregar, 2014).

Namun dari hasil pengukuran indeks glikemik yang dihasilkan dari sagu porno ini sangat tinggi. Respon glikemik yang dihasilkan pada seseorang sangat dipengaruhi pada kebiasaan pengaturan makan mereka dalam sehari-hari. bahan pangan yang dicerna dengan kecepatan yang berbeda pada sistem pencernaan seseorang yang mengakibatkan perbedaan respons kadar glukosa darah. Secara umum dapat dijelaskan bahwa pangan yang memiliki indeks glikemik (IG) tinggi akan sangat cepat menaikkan kadar glukosa pada seseorang, sedangkan pangan yang menaikkan kadar gula darah dengan lambat memiliki IG rendah (Nurdyansyah dkk., 2019).

Cara pengolahan merupakan salah dari banyak faktor yang mempengaruhi indeks glikemik pada suatu produk pangan (Nurdyansyah dkk., 2019). Pengolahan sagu porno dengan cara dibakar pada cetakan diperkirakan memicu respon glikemik yang tinggi. hal itu sesuai pendapat yang menyatakan bahwa proses masak dengan cara menggunakan metode panas kering, seperti pembakaran, mengakibatkan zat gizi karbohidrat pecah yang kemudian membentuk warna gelap (reaksi maillard). Hal ini menyebabkan zat pati pecah menjadi dekstrin, bentuk tersebut menjadikan zat gizi menjadi lebih mudah dicerna. Hasil penelitian pada jagung manis yang diolah dengan cara ditumis, direbus dan dibakar diketahui bahwa nilai indeks glikemik jagung manis dengan cara dibakar lebih tinggi dibandingkan dengan cara pengolahan lainnya (Amalia dkk., 2011). Sementara pada penelitian lainnya yang berbeda yaitu mengenai nilai indeks glikemik pada panganan suweg yang diolah dengan cara dipanggang, dipanggang dan digoreng, dipanggang dan didinginkan diketahui bahwa suweg dengan cara dipanggang memiliki nilai indeks glikemik lebih tinggi dibanding cara olahan lainnya (Nurdyansyah dkk., 2019).

Penelitian lainnya juga menjelaskan bahwa metode memasak dengan cara dipanggang pada kentang dapat menghasilkan indeks glikemik lebih tinggi dibandingkan dengan metode memasak lainnya (Nayak et all, 2014). Hal itu juga diperkuat bahwa metode dengan cara di panggang meningkatkan indeks glikemik (allen, 2012).

\section{KESIMPULAN}

Berdasarkan hasil penelitian, maka dapat disimpulkan bahwa nilai indeks glikemik sagu porno adalah 296,53\%, kandungan karbohidrat sagu porno sebesar 50,65\%, kandungan protein sagu porno sebesar $2,06 \%$, Kandungan lemak sagu porno sebesar $11,75 \%$ dan kandungan serat kasar sagu porno sebesar 3,12\%. Saran bagi masyarakat tidak diperkenankan penderita dengan diabetes melitus untuk mengkonsumsi sagu porno sebagai makanan pokok. Bagi institusi pendidikan perlu melakukan sosialisasi dan edukasi pendidikan terhadap temuan ilmiah dari kandungan gizi dan nilai indeks glikemik dari sagu porno. 


\section{DAFTAR RUJUKAN}

Allen, Jonathan C. 2012. Glycemic Index of Sweet Potato as Affected by Cooking Methods. The Open Nutritional Journal, 6(1), 1-11. DOI: $10.2174 / 1874288201206010001$

Amalia, S. N., Rimbawan, \& Dewi, M. 2011. Nilai indeks glikemik beberapa jenis pengolahan jagung manis (Zea mays saccharata Sturt). 6(1), 6-41. https://doi.org/10.25182/jgp.2011.6.1.3641

FAO heat. 1998. Carbohydrates In Human Nutrition. fao.org

Hendriadi, A. 2018. Pengembangan pangan lokal dalam mendukung diversifikasi pangan dan perbaikan kualitas konsumsi pangan masyarakat. tourism,Gastronomy and Destination International conference (TGDIC), Jakarta.

Kemenkes, R. I. 2017. Tabel komposisi pangan Indonesia. Direktorat jenderal Kesehatan Masyarakat Direktorat Gizi Masyarakat.

Kemenkes, R. I. 2018. Riset Kesehatan Dasar Tahun 2018. Kemenkes Republik Indonesia.

Monro, J. A., \& Shaw, M. 2008. Glycemic Impact, Glycemic Glucose Equivalents, Glycemic Index, and Glycemic Load: Definitions, Distinctions, and Implications. The American Journal Clinical Nutrition, $\quad$ 87(1), $\quad$ 237S-243S https://doi.org/10.1093/ajcn/87.1.237s
Nayak, Balunkeswar, Berrios, Jose De J., \& Tang, Juming. 2014. Impact of food processing on the glycemic index (GI) of potato products. Food Reserach Intenational 56, 35-46. http://dx.doi.org/10.1016/j.foodres.2013.12.020

Nurdyansyah, F., Retnowati, E. I., Muflihati, I., \& Muliani, R. 2019. Nilai indeks glikemik dan beban glikemik produk olahan Suweg (Amorphophalus campanulatus BI). jurnal Teknologi Pangan, 13(1), 76-85.

Regina, G. 2012. Daftar indek glikemik makanan. Diaetesmelitus.org. http://diabetesmelitus.org/daftar-indeksglikemik-makanan/

Rimbawan, \& Siagian, A. 2004. Indeks Glikemik Pangan. Penebar Swadaya.

Similia, M. 2012. Glycemic Index in Epidemiologic Study of Type 2 Diabetes [Academic Dissertation,]. University of Helsinki.

Sinulingga, S. (2012). Metode Penelitian (2 ed.). USU Press.

Siregar, N. S. (2014). Karbohidrat. Jurnal Ilmu Keolahragaan, 13(2), 38-44. 